\title{
The Influence of Work Overload, Time Pressure and Social Influence Pressure on Auditors' Job Performance
}

\author{
Razana Juhaida Johari ${ }^{1}$, Nordayana Sri Ridzoan ${ }^{2}$ \& Arumega Zarefar $^{3}$ \\ ${ }^{1}$ Fakulti Perakaunan, Kampus Shah Alam, Selangor, Malaysia \\ ${ }^{2}$ Jabatan Audit Negara, Putrajaya, Selangor, Malaysia \\ ${ }^{3}$ Universitas Riau, Pekanbaru, Indonesia \\ Correspondence: Arumega Zarefar, Universitas Riau, Pekanbaru, Indonesia.
}

Received: April 20, 2019

doi:10.5430/ijfr.v10n3p88
Accepted: May 7, 2019

Online Published: May 19, 2019

URL: https://doi.org/10.5430/ijfr.v10n3p88

\begin{abstract}
Auditing is considered a stressful occupation as the job is always characterized by heavy workloads, many deadlines, time pressure, social pressure and commitment towards the organization. Public auditors are often under pressure to produce quality audit, and yet may be under serious work pressure or continually dealing with auditees in stressful situations. Work stress faced by public auditors also may lead to mental and physical distress which resulted to decrease in job performance. This study examines which potential factors of pressure that have a significant relationship to government auditors' job performance. Factors to be test in this study are work overload, time pressure and social influence pressure. This current study contributes information and ideas to the management and academician in the theoretical and practical aspects. The respondents in this study are 203 government auditors from government auditors in National Audit Department of Malaysia. The result of this study shows that there is no significant relationship on work overload to auditors' job performance. However the result of this study found that factor of time pressure shown a positive significant relation on auditors' job performance, while social influence pressure shown a negative significant relationship on auditors' job performance.
\end{abstract}

Keywords: government auditor, work overload, time pressure, social influence pressure, job performance

\section{Introduction}

Government audit quality plays a vital role for the efficiency of government system and the efficiency of the government administration. Thus, ensuring audit quality on auditors' job performance becomes an important approach to increase the value of resources and stimulate economic development of the country. The government auditors' precise judgements are needed to ensure the public money is being used economically and efficiently. Therefore, the government auditors (hereafter referred to as auditors) become important agents to the government in ensuring a good perception and also a good reputation in conduct of the government agencies. However, auditors faced many influential factors, which could affect their job performance. This issue becomes critical since it is the auditors' role in monitoring the management of government money.

The quality of audit works between the auditors is determined by their job performance (Lee et al., 2016). Job performance is highly related with the quality of audit. Auditors with poor job performance will produce a low audit quality which could result to produce substandard auditing. According to McNamara and Liyanarachchi (2008) showed that amount of audit task could interpreted by the quality of work audit. With this regard, as previously mentioned, the auditors from National Audit Department are responsible to conduct all the three types of audit (i.e. financial audit, compliance audit and performance audit) for the federal and state government agencies in which these could challenge their job performance due to various areas of audit works. Financial audit is to ensure a thorough accounting and fit financial system; therefore, it will verify that accounting transactions are under proper control and authorisation (Loke et al., 2016; Suy, Chhay \& Choun 2018). Whereas, a compliance audit is mandatory under the Malaysian Audit Act, 1957 (National Audit Department., 2018). This type of audit verifies that all expenditure incurred has been approved and are in accordance with policies, laws and regulations (Loke et al., 2016). A part of that, Audit Act 1957 incorporated the mandatory requirement for the Auditor General to undertake a performance audit in ensuring public funds were managed economically, efficiently and effectively. 
The public places their interest on the auditor's general audit report as it discloses the real situation, condition and current position on financial position, an equitable of expenditure, and also the organization's internal control in managing the government money have been audited by the National Audit Department. Notably, in each year, the auditors of the National Audit Department are required to perform all the three types of audit on 465 agencies that includes 145 federal agencies and 320 states government agencies. These processes were allocated to be completed within 1 to 3 months for financial audit, 3 months for compliance audit and 4 months for performance audit. This fact shows that the intensity of the responsibilities held by the auditors are very vast and somehow it could affect the auditors' job performance.

Kakkos and Trivellas (2011) noted that significant factors which affected job performance are work overload, time pressure and social influence pressure and these indirectly affect the quality of audit. Empirically, there are many scholars (e.g. Wijaya \& Yulyona, 2017; Cabral \& Lazzarini, 2014; Walker, Boyne \& Brewer, 2010) have examined the effect of these three factors on job performance among auditors; however, there are limited studies that have been conducted on government auditors. This limitation occurs due to diverse circumstances faced during the auditing process and the fact that they are reporting on the real performance and financial position of the federal and state government agencies. Therefore, this current study investigates the possible effect of the relationship between work overload, time pressure and social influence pressure on government auditors' job performance. In addition, this study also fulfils the gap of the lacking studies that focus on government auditors at National Audit Department of Malaysia.

\subsection{Research Objectives and Research Questions}

The research objective is mainly to investigate factors that affect job performance among the government auditors. The work overload, time pressure and social influence pressure as the independent variables in this study are, while job performance as the dependent variable. The specific objectives of the study are as follows:

1. To examine the relationship between work overload and government auditors' job performance.

2. To analyse the relationship between time pressure and government auditors' job performance.

3. To analyse the relationship between social influence pressure and government auditors' job performance.

\section{Literature Review and Hypotheses Development}

\subsection{Public Sector Auditing}

Auditing is essential for ensuring that the public sector's management and funds are administered in effectively and efficiently. Similarly, auditors' performance is very sensitive for reinforcing accountability and integrity, improving processes, and instigating a feeling of confidence among various stakeholders especially the citizens. Auditors' work should provide either or all of three outcomes: oversight, insight and foresight. Omission is concerned with the correctness of mismanagement and avoiding corruption. Insight is concerned with providing decision makers an independent and balanced assessment of the public sector's programs, policies, operations, and outcomes. Meanwhile, foresight is based on the identification of emerging trends and challenges. Several types of auditing are usually accomplished to achieve each of these outcomes including financial audits report, performance audits report, investigations audit report, compliance audit report and advisory services report (Goodson, Mory \& Lapointe, 2012; Tang \& Khan 2018).

\subsection{National Audit Department in Malaysia}

Auditing is an organised examination, analysis and evaluation of financial statements, records, operations, and the administration of an organization, in order to determine whether it adheres to general principles of accounting, and to management policies and procedures. The Federal Constitution and the Audit Act 1957, in Article 106, stated the Auditor General's authority to audit the accounts of the federal and state governments, government agencies, public authorities and other government company. All the auditing programs are usually conducted by auditors from the National Audit Department in Malaysia (National Audit Department of Malaysia, 2018).

The Auditor General's obligations include producing reports on the financial management and activities of the federal government, state departments, and associated organizations. According to its 2011 - 2015 strategic plans, the National Audit Department's main objectives are (i) to implement audit activities and to prepare independent and unbiased reports for the attention of the parliament and state legislators (ii) to manage the audit activities efficiently and effectively, to fulfil the needs and expectations of stakeholders (iii) and to be a ideal department.

Based on these main objectives, public sector auditors ultimately aim for high quality job performance in terms of reporting efficiency, cooperative working culture and continuous professional development (Buang, 2012). Auditors' 
job performance lies in their ability to identify omissions, misstatements or frauds in the user's financial statements (Fearnley \& Beattie, 2004). In a typical setting, poor performance is explained into the auditors' incapability to detect and report irregularities in the users' documents (Mohd Nor, 2011; Suy, Choun \& Chhay 2018).

\subsection{Job Performance}

Researchers on job performance have been done by decades, and it is one of the essential criteria in determining organizational effectiveness. According to Borman and Motowidlo (2014), for achieving organizational effectiveness there are two categories of employee behaviours which namely as task performance and contextual performance. Task performance refers to when employees perform activities which relate to the organization's technical core whether directly [by implementing technical processes] or indirectly [by providing required materials] (Borman \& Motowidlo, 2014). Besides that, contextual performance is defined as activities which contribute to the socio-psychological core of an organization, and is equally significant to task performance in driving effectiveness (Werner, 2000). A study done by Mahdavi \& Daryaei (2017) found that auditors are considered as actors which also have no exception whereby various factors could affect their performance.

Auditors' job performance could also be interpreted as audit quality and has been measured from few perspectives such as effectiveness and efficiency of auditors in conducting audit procedures and decision making performance (Mohd Nor, 2011). Auditors' job performance is important as it influences audit quality which caused accounting and auditing scandals to occur frequently that largely impacted the profession and public due to the deficiency on auditors' performance (Kalbers \& Cenker, 2008). Auditors' job performance could also be interpreted as the ability of auditors to achieve the department objectives emphasized on quality opinion (Loke et al., 2016).

Homocianu and Airinei (2014) showed that the dynamics and responsibility of financial auditors in experienced and professional can meet persistent need for fair presentation of financial reports and statements of each organization in accordance with legal frameworks that benefits investors, creditors, government and people. In another meaning, job performance can be described as the ability of individuals to achieve their respective work aims, then meet their expectations, achieve benchmarks or accomplish their organizational goals (Ismail, Suh, Ajis, Dollah, 2009). Furthermore, as any one individual is different from other individuals in terms of ability and personality, most companies tend to evaluate employees based on their individual job performance. In auditing, individual job performance is very important and must be handled appropriately since it affects the quality of audits whereby compromises with job performance may produce substandard audit quality and consequently lead to potential legal liabilities and loss of credibility for the organization (Olasanmi, 2016; Takele, 2018).

\subsection{Work Overload}

Workload refers to the greatness of job tasks, and might cause mental distress for employees. People respond differently towards workload. Some embraces it, while others show frustration. As employees climb the employment stairs, workload increases, which influences workers' job performance (Schultz \& Schultz, 2015), and this concerns managers who are nowadays seeking only high performing persons (Malta, 2004). The literature suggests that pressure is considered as a source of reducing job performance (Schultz \& Schultz, 2015). Additionally, workload refers to the concentration or the amount of assignments and tasks, which employee responsible at work (Ali \& Farooqi, 2014). This aspect refers to the degree of stress experienced by individuals due to the conception that they are unable to adapt or be active with the amount of work assigned to them (Idris, 2011)

According to Perselin, Schmidt \& Wilkins (2014), majority of the Big 4 audit firms in the US agreed that audit quality begins to deteriorate when they start to work in excess of 60 hours per week and only $29 \%$ of respondents believe that the quality of audit work is not impacted by the number of hours worked. Karatepe (2013) also noted that the existence work overload lead to ineffective job performance. In other words, Chadegani, Mohamed \& Iskandar (2015), and Ali and Farooqi (2014) initiate that employees will begin to deterioration tasks when they are exposed to more than they can undertake. This is the actually case during the peak periods whereby the employees subjected to high overload for numerous public sector entities. However, the association between workload and job performance is occasionally non-linear. According to Bruggen (2015), the association might take the shape of an inverted U-shape. Whereby, employees' productivity increases up to a certain point after which it, it will turn down or decreases. Therefore, this finding supports that performance is highest under moderate workload levels.

Previous findings concerning the influence of work overload on government auditors' job performance are mostly inconsistent and contradicting. Whereby, past studies provided varying results presenting that workload, at times, negatively influences job performance (e.g. Yan \& Xie, 2016; Shah et al., 2011; Yang et al., 2014). However, at other times, it exhibits a positive effect on job performance (Bruggen, 2015). Nevertheless, there are also some 
limited studies that found no relationship between work overload and job performance (e.g. Khan \& Akbar, 2015; Ahuja et al., 2007; Qureshi et al., 2012). Consequently, based on these discoveries, the first hypothesis is formulated as follows:

H1: There is a relationship between work overload and government auditors' job performance.

\subsection{Time Pressure}

Time Pressure is a person's opinion concerning their ability to complete a task based on a time limitation, it explain that a timely task completion reflects the effectiveness and efficiency in task performance (DeZoort \& Lord, 1997). Previous study which engaged either quantitative or qualitative methods (e.g. Wijaya \& Yulyona, 2017; Broberg, Tagesson, Argento, Gyllengahm \& Martensson, 2017; Svanberg \& Ohman, 2016) had showed that audit time budget pressure has been increasing. DeZoort and Lord (1997) provided a comprehensive review of prior time budget and time deadline pressure associated to the research in accounting. The researchers added that dysfunctional behaviour correlates strongly with time pressure and have an impact on audit quality. In other words auditors must have a strategy to cope with the situation where relating to the suppression time and behaviour during auditing process.

Research by Pietsch and Messier (2017) and Svanberg and Ohman (2013) suggested that a moderate increase in time deadline pressure improves job effectiveness. However, US studies showed that auditors believe that time budgets are difficult to manage and this can affect audit quality (McNamara \& Liyanarachchi, 2008). Lee (2012) indicated that a step increase in time deadline pressure yields declined performance. It is important that time deadline pressure happens due to the external and internal factors to the audit organization, which suggests less possibility of its elimination (Kelley et al., 2005). However, study proposes that deal with time pressure is possible either by increasing auditors' efforts or by search for information. This should produce logic of accomplishment and achievement of appreciation and gratitude (Podsakoff, LePine, \& LePine, 2007). Another study done by Braun (2000) examined the effect of time pressure on auditors' attention to red flags. Their study found that $25 \%$ of respondents reported that, as a consequence of time pressure, they had performed somewhat superficial reviews of client documents on their most recent audit.

Notably, past studies suggested that time pressure influences audit effectiveness (Hyatt \& Lovig, 2002; Margheim et al., 2005). Indeed, the literature is consensus that time pressure and job performance was negatively correlated (e.g. Brown \& King, 2010; Ismail \& Tan, 2011). Recent research such as Broberg at al. (2017) and Abuaddous et al. (2015) also revealed the same result of a negative influence of time pressure on audit performance. However, Wijaya and Yulyona (2017) as well as Sacramento, Fay \& West (2013) found that there is no association between time pressure and job performance. Therefore, due to the contradicting finding in the current research conducted, it is hypothesized that:

$\mathrm{H} 2$ : There is a relationship between time pressure and government auditors' job performance.

\subsection{Social Influence Pressure}

Social pressure results in the influence of someone's performance by significant others (Bishop, DeZoort \& Hermanson, 2016; Nasution, \& Ostermark, 2012). Ghanaee, Rojuee \& Ghanbari (2015) explained that there are two main social influence pressures that could affect auditors' performance i.e. (i) obedience pressure and (ii) conformity pressure. Obedience pressure results from instructions made by persons who have power (Brehm \& Kassin, 1990), which affect subordinates' behaviours. Nevertheless, conformity pressure is defined as pressure associated to the influence on the individuals between each other in the organization. It results from the behaviours of colleagues or peers, also denoted to as peer pressure. Fundamentally, persons who are affected group norms may respond according to them (DeZoort \& Lord, 1997). People frequently adapt to their peers' behaviours since they fear the negative consequences of acting differently, e.g. social isolation (Brehm \& Kassin, 1990).

Two categories of social influence pressure, obedience and conformity, encourage dysfunctional behaviours in auditors. Previous literature examining on the auditors' response to obedience pressure discloses that inappropriate managerial orders significantly increased auditors' tendency to make unethical decisions which lead to a decrease of job performance (e.g. Chong \& Syarifuddin, 2010; Davis et al., 2006; Svanberg \& Ohman, 2013).

Prior literature investigating on auditors' response to pressure reveals that inappropriate managerial instructions significantly increased auditors' tendency to make unethical decisions (DeZoort and Lord 1994). However, other previous studies which assessed the influence of social pressure are limited such as Lord and DeZoort, (2001) and Wijaya and Yulyona, (2017) which provided contradicting results. Ponemon's (1992) result showed that auditors are more likely to underreport their time when they face the social pressure in which decreases their job performance. In contrast, Lord and DeZoort (2001) and Wijaya and Yulyona (2017) revealed that these pressure does not increase 
auditors' preparedness to sign off inaccurate financial statements which increase their job performance. Therefore, based on the inconsistent result of the past studies, it is hypothesized that:

H3: There is a relationship between social influence pressure and government auditors' job performance.

\section{Methodology}

\subsection{Sample Selection}

The population for this study are the auditors who currently worked with the National Audit Department in Peninsular Malaysia, Sabah and Sarawak. Currently, there are 2,041 auditors serving at the National Audit Department in Malaysia (National Audit Department, 2017). The selected respondents for this study consisted of auditors from three levels which were the Top Management, Management and Professional and Support Staff. A total of 400 questionnaires have been distributed via personal official e-mail

\subsection{Data Collection}

In order to achieve the research objective of this study, 400 set of introductory letter, questionnaires and stamped reply envelope were distributed through electronic mail, postal, Google forms and personally to the government auditors in the Sector of Federal Statutory Body Audit, Sector of Federal Government Audit and Sector of State Government Audit in Peninsular Malaysia, Sabah and Sarawak respectively. From the 400 set of questionnaires distributed, 203 were returned (51 percent response rate) and 197 were uncollectable due to no response.

\subsection{Measurement of Variables}

The questionnaire contained three sections. Section A consisted of three independent variables namely the time pressure, work overload and social influence pressure. Section B was designed to get the opinion regarding the dependent variable i.e. the job performance. Finally, Section $C$ was a set of demographic questions. The measurement used for this section was interval scale based on a five-point Likert scale ranging from 1 (strongly disagree) to 5 (strongly agree). All variables used in this current study were already being tested in the past studies conducted in Western countries, Middle East country and Malaysia. Thus, statistically, the variables' reliability and validity were confirmed.

Measurement of variables for this study was based on questionnaires adapted from different journals.

(i) Job performance was measured using five questions in a self-reported performance evaluation instrument developed by Fogarty, Jagdip, Gary \& Ronald (2000) and tested by other researchers (e.g. Kalbers \& Cenker, 2008; Utami \& Nahartyo, 2013; Suhayati, 2012).

(ii) Time pressure was measured using the measurement items developed by Beehr, Walsh \& Taber (1976) and tested by several researchers (e.g. Mohd Nor, 2011; Karatepe, 2013; Qureshi et al., 2013) on their studies toward the private auditor in Malaysia and other countries.

(iii) Time pressure was measured with the five measurement items adapted from DeZoort (1997) and Liyanarachchi and Shaun (2007). The measurement items have been used in Liyanarachchi and Shaun (2007) and Suhayati (2012) in examining the effect of time pressure on audit quality.

(iv) Social influence pressure was measured with the adapted five indicators developed by Lord and DeZoort (2001) and tested by Ahson and Asokan (2004) and Sulityawati et al. (2011).

Finally, the final section is identified as Part C: Demographic Information. This section in nominal scale requires the respondents to answer their demographic information such as gender, race, age, marital status, academic qualification, background qualification, and job position, sector of working, working state and working experience in current position. The intention of this section is to identify the background of the respondents.

\section{Results Analysis}

\subsection{Demographic Profile of the Participants}

The demographic information consists of gender, race, age, marital status, academic qualification, background qualification, job position, sector of working, and working experience. Table 1 demonstrates the demographic data for the respondents from 203 usable responses. 
Table 1. Respondent's profile

\begin{tabular}{|c|c|c|c|}
\hline Demographic Profile & & $\begin{array}{l}\text { Frequency } \\
(n=203)\end{array}$ & Percentage $(\%)$ \\
\hline \multirow[t]{2}{*}{ Gender: } & Male & 46 & 22.7 \\
\hline & Female & 157 & 77.3 \\
\hline \multirow[t]{4}{*}{ Age Group: } & Below 30 years & 31 & 15.3 \\
\hline & Between 30 to 40 years & 129 & 63.5 \\
\hline & Between 41 to 50 years & 32 & 15.8 \\
\hline & More than 51 years & 11 & 5.4 \\
\hline \multirow[t]{2}{*}{ Marital Status: } & Single & 21 & 10.3 \\
\hline & Married & 182 & 89.7 \\
\hline \multirow[t]{4}{*}{ Race: } & Malay & 176 & 86.7 \\
\hline & Chinese & 15 & 7.4 \\
\hline & Indian & 9 & 4.4 \\
\hline & Others & 3 & 1.5 \\
\hline \multirow[t]{4}{*}{ Education Level: } & Diploma & 104 & 51.2 \\
\hline & Degree & 82 & 40.4 \\
\hline & Professional & 12 & 5.9 \\
\hline & Master & 5 & 2.5 \\
\hline Qualification & Accounting & 186 & 91.6 \\
\hline Background: & Non-accounting & 17 & 8.4 \\
\hline \multirow[t]{3}{*}{ Job Position: } & $\begin{array}{l}\text { Supporting staff } \\
\text { (Grade 22-40) }\end{array}$ & 104 & 51.2 \\
\hline & Management and Professional (Grade 41-54) & 98 & 48.3 \\
\hline & Top management (Grade JUSA C and above) & 1 & 0.5 \\
\hline \multirow[t]{4}{*}{ Audit Sector: } & Federal Government & 54 & 26.6 \\
\hline & State Government & 54 & 26.6 \\
\hline & Federal Statutory Body & 90 & 44.3 \\
\hline & Others & 5 & 2.5 \\
\hline Working & Below 5 years & 32 & 15.8 \\
\hline \multirow[t]{3}{*}{ Experience: } & $6-10$ years & 109 & 53.7 \\
\hline & 11-15 years & 36 & 17.7 \\
\hline & 16 years and above & 26 & 12.8 \\
\hline
\end{tabular}

Based on the findings, over three quarter of the respondents were female with 77.3 percent while male represented 22.7 percent of the sample. It was found that auditing field was dominated by females. Most of the respondents $(63.5 \%)$ were at the range of 30 to 40 years while the lowest was 5.4 percent from the age group of 51 years and above. In this study, most of the respondents $(89.7 \%)$ were married compared to those who were single which comprised of 10.3 percent from the total respondents. From the data, majority of the respondent's ethnic breakdown 
showed that a large number were Malay with 86.7 percent, 7.4 percent from Chinese, Indian with 4.4 percent, and other ethnic with 1.5 percent of the sample respectively.

It is also identified that only 2.5 percent had professional qualification such as ACCA, CIMA and CPA and 5.9 percent of the sample has Master qualification. Most of the respondents (51.2\%) were diploma holders while degree holders were 40.4 percent from the total respondents. Majority of the respondents were from accounting background with 91.6 percent while non-accounting background only comprised of 8.4 percent of the total sample. It was noted that 51.2 percent of the respondents were at the level supporting staff with grade within $22-40$ while 48.3 percent worked at the management and professional levels with grade within 41-54 and only 0.5 percent of the respondents were from top management (Jusa C and above). Moreover, almost half of the respondents (44.3\%) were attached at federal statutory body, followed by 26.6 percent working at federal government, 26.6 percent from state government and 2.5 percent from other department.

The data identified that 53.7 percent of the respondents had working experience between six to ten years while 17.7 percent had between eleven to fifteen years of employment experience. Besides that, 15.8 percent of the respondents had one to five years working experience while 12.8 percent of the respondents had more than sixteen years of employment experience. From the analysis, it also showed that majority of the respondents had long employment experience in National Audit Department of Malaysia from different sectors.

\subsection{Normality Test}

Based on Table 2, all the skewness and kurtosis values were within the range of +2 to -2 . As a rule of thumb, data were said to be normally distributed if the skewness and the kurtosis value ranged within -2 to +2 (Garson, 2012). Skewness was used to determine the degree of asymmetry of a distribution around its mean. Data points showed it skewed to the right if the skewness was a positive value, or vice versa.

Table 2. Normality test of sample distribution

\begin{tabular}{llllll}
\hline & N & Skewness & Kurtosis \\
\hline Work Overload & & Statistic & Std. Error & Statistic & Std. Error \\
\hline Time Pressure & 203 & -0.304 & 0.171 & 0.489 & 0.340 \\
\hline Social Influence Pressure & 203 & -0.013 & 0.171 & 0.867 & 0.340 \\
\hline Job performance & 203 & -1.460 & 0.171 & 1.530 & 0.340 \\
\hline Valid N (listwise) & 203 & 0.828 & 0.171 & -0.901 & 0.340 \\
\hline
\end{tabular}

The analysis shows that the distribution of data was normal since the kurtosis was between -0.901 and 1.53 . In addition, Field (2013) stated that for data with more than 30 samples, it can be considered to be normal even it was not normally distributed.

\subsection{Validity Analysis}

Pallant (2005) noted that factor analysis can be used to assimilate and reduce numbers of variables to a smaller numbers of underlying factors which contained all the important information. Below are the validity analysis conducted on each variables.

\subsubsection{Work Overload}

Table 3 shows the result of the factor analysis for work overload variable. The Eigenvalue for the test means that the factor used in work overload stood at 52.893\% of variance. The Kaiser-Meyer Olkin (KMO) test indicated the value at .629 which was higher than $.6($ Chi-Square $=329.855)$ and the significant level was at $\mathrm{p}<0.000$. All the items scored a loading more than 0.50 ; therefore, they were considered practically significant. From the analysis, the sample was adequate to be used in this factor analysis and the test supported the work overload variable for this study. 
Table 3. Factor analysis for work overload

\begin{tabular}{|c|c|c|}
\hline \multicolumn{2}{|c|}{ Kaiser-Meyer-Olkin Measure of Sampling Adequacy. } & 0.629 \\
\hline \multirow[t]{3}{*}{ Bartlett's Test of Sphericity } & Approx. Chi-Square & 329.855 \\
\hline & $\mathrm{df}$ & 10 \\
\hline & Sig. & 0.000 \\
\hline \multirow[t]{3}{*}{ Initial Eigenvalues } & Total & 2.645 \\
\hline & $\%$ of Variance & 52.893 \\
\hline & Cumulative $\%$ & 52.893 \\
\hline \multicolumn{2}{|l|}{ Work Overload } & Factor \\
\hline \multicolumn{2}{|c|}{ [WO1] I know that my job requires me to work very fast } & 0.811 \\
\hline \multirow{2}{*}{\multicolumn{2}{|c|}{$\begin{array}{l}\text { [WO2] I understand that my job requires me to work very hard (physically or } \\
\text { mentally) }\end{array}$}} & 0.673 \\
\hline & & 0.803 \\
\hline \multicolumn{2}{|c|}{ [WO3] I know that my job leaves me with little time to get everything done. } & \\
\hline \multirow{2}{*}{\multicolumn{2}{|c|}{$\begin{array}{l}\text { [WO4] I am aware that my job requires me to work much than one person to } \\
\text { do. } \\
\text { [WO 5] I feel that performance standards on my job are too high. }\end{array}$}} & 0.558 \\
\hline & & 0.760 \\
\hline
\end{tabular}

\subsubsection{Time Pressure}

According to the result of factor analysis for time pressure variable shown in Table 4, the Eigenvalue for the test was at $27.108 \%$ of variance. The Kaiser-Meyer Olkin (KMO) test stood at .563 which was more than .50 (Chi-Square $=$ 134.831 ) and the significant level was at $\mathrm{p}<0.000$. All the items scored a loading of more than 0.50 ; therefore, they were considered practically significant. From the analysis, the sample was adequate to be used in this factor analysis and the test supported the work overload variable for this study.

Table 4. Factor analysis for time pressure

\begin{tabular}{|c|c|c|}
\hline \multicolumn{2}{|c|}{ Kaiser-Meyer-Olkin Measure of Sampling Adequacy } & 0.563 \\
\hline \multirow[t]{3}{*}{ Bartlett's Test of Sphericity } & Approx. Chi-Square & 134.831 \\
\hline & df & 10 \\
\hline & Sig. & 0.000 \\
\hline \multirow[t]{4}{*}{ Initial Eigenvalues } & Total & 1.355 \\
\hline & $\%$ of Variance & 27.108 \\
\hline & Cumulative $\%$ & 63.194 \\
\hline & Time Pressure & Factor \\
\hline \multicolumn{2}{|c|}{ [TP 1] There are many audit tasks that I have to do. } & 0.676 \\
\hline \multicolumn{2}{|c|}{ [TP 2] I am unable to achieve my timeframe } & 0.843 \\
\hline \multicolumn{2}{|c|}{ [TP 3] I feel uncomfortable when time frames are set for my jobs. } & 0.830 \\
\hline \multicolumn{2}{|c|}{ [TP 4] I know that the client is aware of my timeframe. } & 0.558 \\
\hline \multicolumn{2}{|c|}{ [TP 5] There is usually a time deadline for the audit fieldwork } & 0.822 \\
\hline
\end{tabular}

\subsubsection{Social Influence Pressure}

The result of the factor analysis for social influence pressure variable is shown in Table 5. The Eigenvalue for the test indicated $21.289 \%$ of variance. The Kaiser-Meyer Olkin (KMO) test was at .515 which was not lower than .5 $($ Chi-Square $=145.757)$ and the significant level was at $p<0.000$. All items used to measure social influence pressure 
scored a factor loading of above 0.50 . The sample was adequate and supported the social influence pressure variable for this study.

Table 5. Factor analysis for social influence pressure

\begin{tabular}{lll}
\hline Kaiser-Meyer-Olkin Measure of Sampling Adequacy & 0.515 \\
\hline Bartlett's Test of Sphericity & Approx. Chi-Square & 145.757 \\
\hline & df & 10 \\
\hline & Sig. & 0.000 \\
\hline Initial Eigenvalues & Total & 1.064 \\
\hline & \% of Variance & 21.289 \\
\hline & Cumulative \% & 81.729 \\
\hline Social Influence Pressure & & Factor \\
\hline [SI 1] I find it difficult to cooperate with others in a team. & 0.924 \\
\cline { 2 - 2 } [SI 2] I feel that the effort each member contributes to the team is inconsistent & 0.909 \\
\cline { 2 - 2 } [SI 3] I notice that there are some conflicts among other team members when & 0.660 \\
\cline { 2 - 2 } working in the team.
\end{tabular}

[SI 4] I have to disregard certain professional ethical standards and agree to supervisor's request when reporting weaknesses.

0.868

[SI 5] There are things I sometimes have to do that are accepted by supervisor but not accepted by my profession.

0.875

\subsection{Reliability Analysis}

The purpose of the reliability test is to measure the consistency of the item developed in the questionnaire. The most common measure of reliability test is Cronbach's Alpha. In the Cronbach's Alpha, the acceptable and more suitable value is 0.7 (Kline, 2009). In the following sections, results of the statistical tests on the variables under study were discussed. Meanwhile, the result of the Cronbach's Alpha is above 0.7, which shows acceptable reliability. Based on the guideline by Kline (2009), reliability of 0.7 or above was acceptable.

Table 6. Reliability test

\begin{tabular}{llll}
\hline Construct & Variables & Cronbach's Alpha & Number of Items \\
\hline WO & Work overload & 0.747 & 5 \\
\hline TP & Time pressure & 0.709 & 5 \\
\hline SI & Social influence pressure & 0.774 & 5 \\
\hline JP & Job performance & 0.714 & 5 \\
\hline
\end{tabular}

\subsection{Correlation Analysis}

Referring to Table 7, there are positive relationships between work overload, time pressure, social influence pressure and job performance. The analysis finds that the correlation between job performance as the dependent variable correlated in a weak relationship with all the independent variables whereby the correlations fell below .29 except a strong relationship with time pressure with a score of .554 (significant at $\mathrm{p}=.000$ ). Another weak correlation with job performance were work overload and social influence pressure with scores of .124 (significant at $p=.007$ ) and .171 (significant at $\mathrm{p}=.001)$. 
Table 7. Correlation analysis

\begin{tabular}{lllll}
\hline & $\begin{array}{l}\text { Work } \\
\text { Overload }\end{array}$ & $\begin{array}{l}\text { Time } \\
\text { Pressure }\end{array}$ & $\begin{array}{l}\text { Social } \\
\text { Pressure }\end{array}$ & Influence \\
\hline Work Overload & 1 & $.250^{* *}$ & $.298^{* *}$ & 0.124 \\
\hline Time Pressure & 1 & $.588^{* *}$ & $.554^{* *}$ \\
\hline Social Influence Pressure & & 1 & $.171^{*}$ \\
\hline Job performance & & & 1 \\
\hline
\end{tabular}

**. Correlation is significant at the 0.01 level (2-tailed).

*. Correlation is significant at the 0.05 level (2-tailed).

In addition, there was a strong correlation between independent variables which were social influence pressure and time pressure with a score of .588 (significant at $\mathrm{p}=.000$ ). It noted a weak correlation between social influence pressure and work overload with a score of .298 (significant at $\mathrm{p}=.000$ ). In the meantime, the correlation between time pressure and work overload stated a weak relationship with a score of .250 (significant at $p=.000$ ). From the analysis, none of the variables were rejected from this study.

\subsection{Multivariate Analysis}

In this study, multiple regression analysis was used to test the linear relationships between the auditors' work overload, time pressure, and social influence pressure with the auditors' job performance.

\subsubsection{Multicollinearity Test}

In this analysis, the results obtained indicated that multicollinearity did not exist as tolerance values for all independent variables were between 0.628 and 0.902 which were more than .10 . This was also supported by the VIF values which stood between 1.108 and 1.589 which were less than 10. Therefore, from the result shown in Table 8 below, this current study did not have any problem with multicollinearity.

Table 8 . Collinearity test

\begin{tabular}{lll}
\hline \multirow{2}{*}{ Model } & Collinearity Statistics & \\
\cline { 2 - 3 } & Tolerance & VIF \\
\hline (Constant) & & \\
\hline Work overload & .902 & 1.108 \\
\hline Time Pressure & .648 & 1.544 \\
\hline Social Influence & .628 & 1.589 \\
\hline a. Dependent Variable: Job Performance & & \\
\hline
\end{tabular}

\subsubsection{Regression Analysis}

Results in Table 9 presents the analysis conducted on the relationship between all of these independent variables namely work overload, time pressure and social influence pressure on auditors' job performance. Empirically, only two of the independent variables i.e. time pressure and social influence pressure were found to significantly affect the auditors' job performance.

Table 9. Regression analysis

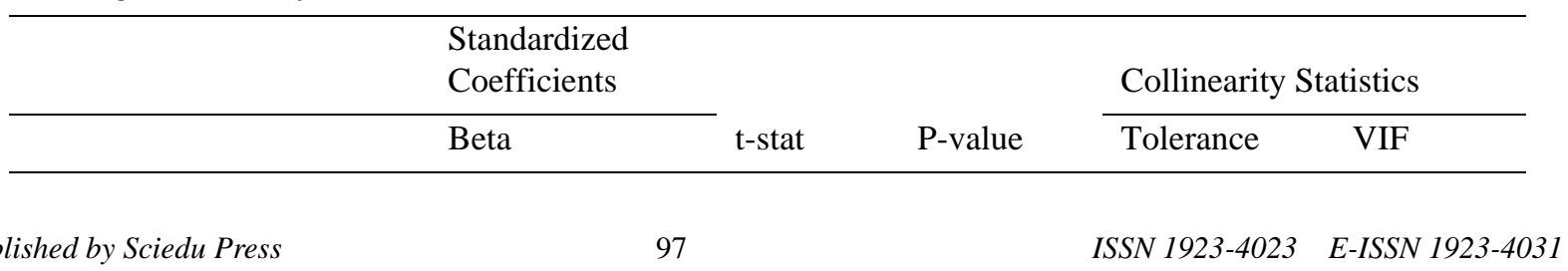




\begin{tabular}{llllll}
\hline (Constant) & & 8.656 & 0.000 & & \\
\hline Work Overload & 0.024 & 0.396 & 0.693 & 0.902 & 1.108 \\
\hline Time Pressure & 0.691 & 9.680 & $0.000^{* *}$ & 0.648 & 1.544 \\
\hline Social Influence Pressure & -0.243 & -3.354 & $0.001 * *$ & 0.629 & 1.589 \\
\hline
\end{tabular}

Dependent Variable: Job performance

\begin{tabular}{ll}
\hline $\mathrm{R}$ & $=.586^{\mathrm{a}}$ \\
\hline $\mathrm{R}^{2}$ & $=.344$ \\
\hline $\mathrm{R}^{2}$ (Adjusted $\left.\mathrm{R}^{2}\right)$ & $=.334$ \\
\hline Std. Error of the Estimate & $=0.32298$ \\
\hline Durbin-Watson & $=0.333$ \\
\hline $\mathrm{F}$ & 34.775 \\
\hline Sig. & $.000^{\mathrm{b}}$
\end{tabular}

** Significant at 0.01 level.

* Significant at 0.05 level.

The result also indicated that $\mathrm{R}^{2}$ value for the regression was $.344(34 \%)$ while adjusted $\mathrm{R}^{2}$ shows that 0.334 of the variance is explained by work overload, time pressure and social influence pressure the independent variable which means $33.4 \%$ of the changes in the job performance for the dependent variable. Furthermore, the result of the regression analysis identified that the factor of work overload had no influence on auditors' job performance. The finding shows that the coefficient for work overload was $.024, t=.396, p=.693$ where $p>.01$ which is not significant. Therefore, the first hypothesis (H1) was not supported. This finding is consistent with Khan et al. (2015) and Qureshi et al., (2012) who found that work overload have no significant impact on job performance.

On the other hand, time pressure showed a significant positive relationship with job performance when the value of coefficient was $.691, \mathrm{t}=9.680, \mathrm{p}=.000$ where $\mathrm{p}<.01$. The beta coefficient for time pressure was .691 which indicated that for every 1 rise in time pressure, it could contribute to the changes in job performance by .691 . Thus, the second hypothesis (H2) was supported. The result are consistent with the finding of previous studies by Pietsch and Messier (2017) as well as Svanberg and Ohman (2013) who also found the positive influence of time pressure on auditor performance.

Finally, the result also showed that social influence pressure had a significant negative relationship with auditors' job performance when the coefficient value for social influence pressure was $-.243, \mathrm{t}=-3.354, \mathrm{p}=.001$ where $\mathrm{p}<.01$. This result indicated that social influence pressure could influence the auditors' job performance. Therefore, the third hypothesis H3 was also supported. This is supported by previous research findings (e.g. Svanberg \& Ohman, 2013; Chong \& Syarifuddin, 2010; DeZoort \& Lord, 1994) which argue that social influence pressure affecting job performance by decreased in auditors' tendency to make proper decision.

\section{Discussion of Findings}

This study is conducted to examine the factor influencing government auditors' job performance in National Audit Department of Malaysia (NAD). Research objectives were formulated in order to understand the relationship between job performance and set of independent variables namely work overload, time pressure and social influence pressure. In order to attain the objectives of the study, the descriptive and inferential study were conducted. Descriptive statistic was performed to determine the characteristics of the data prior to inferential statistics.

Based on the descriptive results, 51.2 percent or majority of the respondent are those who are working as support staff in the service grade 22 to 40 . Most of them in the age range from 30 to 40 years with 63.5 percent. In addition 53.7 percent of the respondents with 6 to 10 years of working experience and indicated that their experiences in the NAD could have helped them to responses in answering the questionnaires of this study.

The research objectives were developed in order to understand the relationships between the work overload, time pressure and social influence pressure on the auditors' job performance. The overall mean of 3.21 for work overload 
showed that there are neutral agreements from the respondents and proved that the work overload variable is not affected in their job performance. From the analysis tested on the mean for the time pressure independent variables, it showed that the overall mean of 3.62 for time pressure proven that the respondents have high agreement that the existence time pressure variable affected on auditors' job performance. In addition, overall mean for social influence pressure are 3.63 showed that the respondent also have a high agreement whereby social influence pressure could be the factor which affect auditors' job performance.

The first hypothesis H1 anticipates the relationship of work overload on government auditors' job performance. From the analysis conducted, it is found that work overload is not significant in influencing the government auditors' job performance. Therefore, hypothesis H1 is not supported. This finding is consistent with Khan and Akbar, (2015) and Qureshi et al., (2012) who found that work overload have no significant impact on job performance. Relating to this result, if current workload of auditors increased from their usual or routine workload, they will experience stress. Due to this perceived stress they have to exert extra effort to overcome high demand which ultimately affect their performance Most of the time, employees consider work overload as something challenging and interesting, in this particular type of situation it might be positive instead of negatively correlated with job performance (Le Pine, Podsakoff \& Le Pine, 2005). Although, an extraordinary performer accept more duties and responsibilities and more encouraged them to do better and well (Gilboa, Shirom, Fried \& Cooper, 2008), it is clear indication that sometime work overload may motivate individual instead of causing demotivation.

However, the result in this study showed there is a positive relationship between the work overload and auditors' job performance. Furthermore, the result on positive relationship between the work overload and auditors' job performance indicated that the increase in work overload will increase the auditors' job performance. Otherwise, when auditors have lower work overload it will decrease their job performance. This would indicate that, an auditor who is able to use his skills and abilities in overcoming the work overload will tend to complete their task and end up with good job performance as compared to those who are not. In other words, the auditors who are able to optimize their talents and knowledge could complete the task regardless of the work overload (Bruggen, 2015).

The second hypothesis $\mathrm{H} 2$ predicts the relationship between the time pressures on government auditors' job performance in Malaysia. From the analysis, it was identified that the time pressure has a significant positive relationship with the auditors' job performance. Therefore, it is recognized that time pressure could be able to influence the auditors' job performance in Malaysia. This finding is consistent with the findings of previous studies by Pietsch and Messier (2017) as well as Svanberg and Ohman (2013) who also found the positive influence of time pressure on auditor performance. On the other hand, this finding is contradict with study conducted by Sacramento et al. (2013) and Wijaya and Yulyona (2017) which stated that time pressure did not influence the job performance. Therefore, hypothesis $\mathrm{H} 2$ is supported.

In this manner, it is important to remember that lesser amounts of time allow for the achievement of multiple goals (Brown \& King, 2010). This notation is consistent with this current finding whereby, when auditors have a shorten time to complete the audit work, they will produce a high quality audit and increase their job performance. Thus, auditors who have unpressured work situation, it allows them for relaxation, socialization and distraction. As a result, it might decrease their effectiveness or job performance. Otherwise, work under time pressure tends to be task focused that enhances them to complete the task in a given time and simultaneously preserve the quality of audit.

The third hypothesis $\mathrm{H} 3$ forecasts that there is a relationship between social influence pressures on government auditor' job performance. From the analysis, it was noted that the social influence pressure has a significant negative relationship with auditors' job performance. This is supported by previous research findings (e.g. Svanberg \& Ohman, 2013; Chong \& Syarifuddin, 2010; DeZoort \& Lord, 1994) which argue that social influence pressure affecting job performance by decreased in auditors' tendency to make proper decision. Unfortunately, this finding does not support the recent study by Wijaya and Yulyona (2017) as their study revealed a positive effect of the social influence pressure on the auditors' job performance. Therefore, hypothesis H3 is supported.

This finding explains that social influence pressure that confronted by auditors would influenced their decision in making any judgments which affect their job performance. The significant negative relationship reveals from this study explains when the social pressure increase in the auditing working environment, there would be a decrease in the auditors' job performance. Therefore, it is claimed that the auditors who facing no pressure tend to have the highest level of job performance, while auditors facing various pressure tend to have the lowest level of job performance (Bishop et al., 2016). Overall, all the findings of this current study have managed to achieve all the research objectives as well as to answer all the respective research questions as stated in Chapter One.

Finally, from the entire research finding on the factors influencing government auditors' job performance such as 
work overload, time pressure and social influence pressure, it can be conclude that the Inverted U Model by Yerkes and Dodson Law could support the variables tested in this study. Yerkes-Dodson law states that for more challenging tasks, a moderate arousal can enhance performance in part by modifying motivation, but a high levels of arousal can decrease performance due to the reduction in the amount of information that can be processed. It was resulted from the condition when auditors will spend time in coping with stress caused auditors efforts on the job may be reduced, resulting in low performance in the quality of audit report been produced.

When auditors experience the right amount of pressure, they will do their best on the task or work and resulted in best job performance; otherwise, if the auditors encounter high level of pressure, they will demoralize and decrease in their performance due to excessive arousal. The result for all variables are in line to the theory of Inverted $\mathrm{U}$ Model by Yerkes and Dodson Law which is work overload and time pressure and social influence pressure. From the result, it was noted that the increase in work overload will increase the auditors' job performance, whereas for a time pressure indicated when auditors have a shorten time to complete the audit work, they will produce a high quality audit and increase their job performance. Contradict to the last result on social influence pressure, whereby when the social pressure increase in the auditing working environment, there would be a decrease in the auditors' job performance. Hence, the variables tested in this study were supported by theory applied. In conclusion, these findings are largely consistent with the concept that high-quality audits require knowledgeable, skilled and experienced auditors who have sufficient time and resources to perform the audit work and to deal with difficult issues as they arise.

\section{Conclusion}

This study examined the influences of work overload, time pressure and social influence pressure on government auditors' job performance. Therefore, this research serves as a base to separately test each variable under study on government auditors' job performance in Malaysia. Auditing enhances government's function by evaluating legitimacy, economy, efficiency, and effectiveness of how administrative ministries utilize resources. Audit reports can effectively provide opinion and suggestions to further improve the performance towards the public and other government bodies. Therefore, by identifying factors that could enhance their job performance is vital as it could offer some insights to the management. The finding of this study could be used by the management to help their auditors to improve their job performance which is to increase the quality of audit.

The issue on government auditors' job performance in Malaysia was less discussed publicly due to some limitations and restrictions. Therefore, practically, this study could provide the management at National Audit Department of Malaysia in terms of creating awareness to the auditors on the factors that could influence their job performance. In overall, the audit department is suggested to implement some training programs such as stress management to the auditors in order to reduce the level of pressure during peak audit period and time deadline. The training programs should focus on the way to manage stress due to the pressures that they might encounter during auditing work. In return, auditors could directly increase their productivity and be more committed to the organisation since they are able to release their work pressures appropriately.

On the other hand, theoretically, this study contributes to the academicians by providing recent literature and fresh analysis which relates to the issue on auditors' job performance. In addition, this study also provides further evidence on the use of Yerkes and Dodson's Inverted-U Model in explaining the effect of pressures on auditors' performance.

\subsection{Research Limitations and Future Research}

This current study was conducted with some identified limitations. Following each limitation is the recommendation for future study which could be carried out as to improve the mentioned limitation. Variables tested in this study included work overload, time pressure and social influence pressure. Other variables such as personal characteristics of the auditors could be added to the research framework. In other words, future studies have to look into many other variables to prove the variables that can enhance the connection between independent variables and dependent variable.

The second limitation is the challenges to get the respondents from higher position level of auditors i.e. the deputy director, director and JUSA above due to time constraint of conducting this study and their availability to participate in this study. Most of the respondents in this study are from the support staff (assistant auditor) which is the middle rank in the government auditors' position. There are just a few respondents from higher rank auditors such as the team leader and head of the team leader. Due to that, the result may be misinterpreted in terms of the existence of management and professional opinion as they are in different levels, have different views and face a different kind of pressure. Future research could be properly planned as to get the responses from higher rank auditors. A research 
collaboration with the National Audit Department could be one of the alternatives to get official involvement of those higher rank auditors.

The final limitation is the distribution of the questionnaires. In this study, the questionnaires were prepared via URL link and distributed via e-mail to all the selected respondents at National Audit Department official email. Questionnaires were also distributed during any programme held at National Audit Department and sent by mail to all respondents in the states. However, it is quite hard to ensure all of the respondents took actions when the email was sent via email address and mail. Thus, future studies must take another action by getting assistance to assist respondents in completing the questionnaire and explaining uncertain questions to get more respondents and to avoid from getting unreliable responses from the respondents.

\section{References}

Abuaddous, M., Hanefah, M. M., \& Laili, N. H. (2015). Audit Structure, Time Pressure and Judgment Accuracy: A Comparison between Strategic System Audit and Traditional Audit. International Journal of Economics and Finance, 7(8), 53. https://doi.org/10.5539/ijef.v7n8p53

Ahson, U., \& Asokan, A. (2004). Dimensions of pressures faced by auditors and its impact on auditors' independence. A comparative study of the USA and Australia. Managerial Auditing Journal, 19(1), 99-116. https://doi.org/10.1108/02686900410509848

Ahuja, M. K., Chudoba, K. M., Kacmar, C. J., McKnight, D. H., \& George, J. F. (2007). IT road warriors: Balancing work-family conflict, job autonomy, and work overload to mitigate turnover intentions. Mis Quarterly, 1-17. https://doi.org/10.2307/25148778

Ali, S., \& Farooqi, Y. A. (2014). Effect of Work Overload on Job Satisfaction, Effect of Job Satisfaction on Employee Performance and Employee Engagement (A Case of Public Sector University of Gujranwala Division). International Journal of Multidisciplinary Sciences and Engineering, 5(8), 23-30.

Andrews, R., Boyne, G. A., Law, J., \& Walker, R. (2008). Organizational strategy, external regulation and public service performance. Public Administration, 86(1), 185-203. https://doi.org/10.1111/j.1467-9299.2007.00695.x

Barrainkua, I., \& Espinosa-Pike, M. (2015). New insights into underreporting of time: the audit partner context. Accounting, Auditing \& Accountability Journal, 28(4), 494-514. https://doi.org/10.1108/AAAJ-02-2014-1618

Beehr, T. A., Walsh, J. T., \& Taber, T. D. (1976). Relationships of stress to individually and organizationally valued states: Higher order needs as a moderator. Journal of Applied Psychology, 61(1), 41-47. https://doi.org/10.1037/0021-9010.61.1.41

Bishop, C. C., DeZoort, F. T., \& Hermanson, D. R. (2016). The effect of CEO social influence pressure and CFO accounting experience on CFO financial reporting decisions. Auditing: A Journal of Practice \& Theory, 36(1), 21-41. https://doi.org/10.2308/ajpt-51507

Borman, W. C., \& Motowidlo, S. J. (Eds.). (2014). Organizational citizenship behavior and contextual performance: A special issue of human performance. Psychology Press. https://doi.org/10.4324/9781315799254

Bowrin, A. R., \& King, J. (2010). Time pressure, task complexity, and audit effectiveness. Managerial Auditing Journal, 25(2), 160-181. https://doi.org/10.1108/02686901011008963

Boyne, G. A. (2003). What is public service improvement?. Public Administration, 81(2), 211-227. https://doi.org/10.1111/1467-9299.00343

Boyne, G. A., \& Walker, R. M. (2010). Strategic management and public service performance: The way ahead. Public Administration Review, 70(s1). https://doi.org/10.1111/j.1540-6210.2010.02271.x

Braun, R. L. (2000). The effect of time pressure on auditor attention to qualitative aspects of misstatements indicative of potential fraudulent financial reporting. Accounting, Organizations and Society, 25(3), 243-259. https://doi.org/10.1016/S0361-3682(99)00044-6

Brehm, S. S., \& Kassin, S. M. (1990). Social Psychology. Boston: Houghton Mifflin Co.

Broberg, P., Tagesson, T., Argento, D., Gyllengahm, N., \& Martensson, O. (2017). Explaining the influence of time budget pressure on audit quality in Sweden. Journal of Management \& Governance, 21(2), 331-350. https://doi.org/10.1007/s10997-016-9346-4

Bruggen, A. (2015). An empirical investigation of the relationship between workload and performance. Management Decision, 53(10), 2377-2389. https://doi.org/10.1108/MD-02-2015-0063 
Buang, A. (2012). Enhancing Accountability \& Integrity in the Malaysian Public Sector - Are We Doing Enough?. Paper presented at the Perdana Discourse Series \#14, Kuala Lumpur.

Cabral, S., \& Lazzarini, S. G. (2014). The "guarding the guardians" problem: An analysis of the organizational performance of an internal affairs division. Journal of Public Administration Research and Theory, 25(3), 797-829. https://doi.org/10.1093/jopart/muu001

Chaby, L. E., Sheriff, M. J., Hirrlinger, A. M., \& Braithwaite, V. A. (2015). Can we understand how developmental stress enhances performance under future threat with the Yerkes-Dodson law?. Communicative \& Integrative Biology, 8(3), e1029689. https://doi.org/10.1080/19420889.2015.1029689

Chadegani, A. A. (2011). Review of studies on audit quality. International Conference on Humanities, Society and Culture, 20, 312-317. https://doi.org/10.2139/ssrn.2227359

Chadegani, A. A., Mohamed, Z. M., \& Iskandar, T. M. (2015). The Influence of Individual Characteristics on Auditors' Intention to Report Errors. Journal of Economics, Business and Management, 3(7), 710-714. https://doi.org/10.7763/JOEBM.2015.V3.271

Chang, C. J., Luo, Y., \& Zhou, L. (2017). Audit deficiency and auditor workload: evidence from PCAOB triennially inspected firms. Review of Accounting and Finance, 16(4), 478-496. https://doi.org/10.1108/RAF-03-2017-0050

Chong, V. K., \& Syarifuddin, I. (2010). The effect of obedience pressure and authoritarianism on managers' project evaluation decisions. Advances in Accounting, incorporating Advances in International Accounting, 26, 185-194. https://doi.org/10.1016/j.adiac.2010.04.004

Cohen, J. (1969). Statistical power analysis for the behavioral sciences. New York: Academic Press.

Corbett, M. (2015). From law to folklore: work stress and the Yerkes-Dodson Law. Journal of Managerial Psychology, 30(6), 741-752. https://doi.org/10.1108/JMP-03-2013-0085

Davis, S., DeZoort, F. T., \& Kopp, L. S. (2006). The effect of obedience pressure and perceived responsibility on management accountants' creation of budgetary slack. Behavioural Research in Accounting, 18(1), 19-35. https://doi.org/10.2308/bria.2006.18.1.19

DeZoort, F. T., \& Lord, A. T. (1994). An investigation of obedience pressure effects on auditors' judgments. Behavioural Research in Accounting, 6, 1-30.

DeZoort, F. T., \& Lord, A. T. (1997). A review and synthesis of pressure effects research in accounting. Journal of Accounting Literature, 16, 28-85.

DeZoort, T. (1998). Time pressure research in auditing: Implications for practice. The Auditor's Report, 22, 11-13.

Diaz, M. C. (2005). Risk identification and assessment in a risk based audit environment: The effects of budget constraints and decision aid use (Order No. 3231520). ProQuest Dissertations \& Theses Global (305372192). Retrieved from http://search.proquest.com/docview/305372192?accountid=33993

Ettredge, M. L., Bedard, J. C., \& Johnstone, K. M. (2008). Empirical tests of audit budget dynamics. Behavioral Research in Accounting, 20(2), 1-18. https://doi.org/10.2308/bria.2008.20.2.1

Fearnley, S., \& Beattie, V. (2004). The reform of the UK's auditor independence framework after the Enron Collapse: An example of evidence-based policy making. International Journal of Auditing, 8, 117-138. https://doi.org/10.1111/j.1099-1123.2004.00085.x

Fogarty, T. J., Jagdip, S., Gary, K. R., \& Ronald, K. M. (2000). Antecedents and consequences of burnout in accounting: Beyond the role stress model. Behavioral Research in Accounting, 12, 31-68.

Ghanaee, K., Rojuee, M., \& Ghanbari, F (2015). The Impact of National Culture on Auditors' Responses to Social Influence Pressure.

Gibbins, M. (1984). Propositions about the psychology of professional judgment in public accounting. Journal of Accounting Research, 103-125. https://doi.org/10.2307/2490703

Gilboa, S., Shirom, A., Fried, Y., \& Cooper, C. (2008). A meta-analysis of work demand stressors and job performance: examining main and moderating effects. Personnel Psychology, 61(2), 227-271. https://doi.org/10.1111/j.1744-6570.2008.00113.x

Goodson, Mory, \& Lapointe. (2012). Supplemental Guidance: The Role of Auditing in Public Sector Governance (2nd ed.). The Institute of Internal Auditors. 
Hair, J., Black, W., Babin, B., Anderson, R., \& Tatham, R. (2012). Multivariate data analysis (6th ed.). Upper saddle River, N.J.: Pearson Prentice Hall.

Hair, J., Hult, G., Ringle, C., \& Sarstedt, M. (2013). In A Primer on Partial Least Squares Structural Equation Modeling (PLS-SEM). Thousand Oaks: Sage.

Homocianu, D., \& Airinei, D. (2014). Business intelligence facilities with applications in auditing and financial reporting. Financial Audit (Audit Financial), 12(117), 3-16. https://doi.org/10.2139/ssrn.2502552

Hossain, S. (2010). From project audit to performance audit: evolution of performance auditing in Australia. The IUP Journal of Accounting Research and Audit Practices, 9(3), 20-46.

Hyatt, T. A., \& Lovig, A. L. (2002). Senior auditors' response to premature sign-off by a staff member: Additional insights. Paper Presented at the American Accounting Association Audit Mid-Year Meeting, Research Roundtable, Orlando, FL.

Idris, M. (2011). Over time effects of role stress on psychological strain among Malaysian Public University Academics. International Journal of Business and Social Science, 4(1), 44-48.

Idris. (2014). MIA Practice Review Report 2009-2013.

Ismail, A., Suh, Y., Ajis, M., \& Dollah, N. (2009). Relationship between Occupational Stresses, Emotional Intelligence and Job Performance: An Empirical Study in Malaysia. Theoretical and Applied Economics, 3-16.

Jamal, M. (2011). Job stress, job performance and organizational commitment in a multinational company: An empirical study in two countries. International Journal of Business and Social Science, 2(20).

Jones, R., \& Pendlebury, M. (2000). Public Sector Accounting (5th ed.). Prentice Hall, London.

Kakkos, N., \& Trivellas, P. (2011). Investigating the link between motivation, work stress and job performance. Evidence from the banking industry. In 8th international conference on enterprise systems, accounting and logistics (pp. 408-428).

Kalbers, L. P., \& Cenker, W. J. (2008). The impact of exercised responsibility, experience, autonomy, and role ambiguity on job performance in public accounting. Journal of Managerial Issues, 20(3), 327-347.

Karatepe, O. M. (2013). The effects of work overload and work-family conflict on job embeddedness and job performance: The mediation of emotional exhaustion. International Journal of Contemporary Hospitality Management, 25(4), 614-634. https://doi.org/10.1108/09596111311322952

Karatepe, O. M., Beirami, E., Bouzari, M., \& Safavi, H. P. (2014). Does work engagement mediate the effects of challenge stressors on job outcomes? Evidence from the hotel industry. International Journal of Hospitality Management, 36, 14-22. https://doi.org/10.1016/j.ijhm.2013.08.003

Kelley, T., Margheim, L., \& Pattison, D. (2005). Survey on the differential effects of time deadline pressure versus time budget pressure on auditor behaviour. Journal of Applied Business Research, 15(4), 23-36. https://doi.org/10.19030/jabr.v15i4.5666

Khan, M. T. I., \& Akbar, A. (2015). Impact of Stressors on Employee Performance: Moderating Role of Big Five Traits.

Krejcie, R. V., \& Morgan, D. W. (1970). Determining sample size for research activities. Educational \& Psychological Measurement, 30(3), 607-610. https://doi.org/10.1177/001316447003000308

Lambert, T. A., Jones, K. L., Brazel, J. F., \& Showalter, D. S. (2017). Audit time pressure and earnings quality: An examination of accelerated filings. Accounting, Organizations and Society, 58, 50-66. https://doi.org/10.1016/j.aos.2017.03.003

Le Pine, J. A., Podsakoff, N. P., \& Le Pine, M. A. (2005). A meta-analytic test of the challenge stressor-hindrance stressor framework: An explanation for inconsistent relationships among stressors and performance. Academy of Management Journal, 48(5), 764-775. https://doi.org/10.5465/amj.2005.18803921

Lee, H. (2012). Incentive contracts and time pressure on audit judgment performance. Managerial Auditing Journal, 27(3), 263-283. https://doi.org/10.1108/02686901211207492

Lee, S. C., Su, J. M., Tsai, S. B., Lu, T. L., \& Dong, W. (2016). A comprehensive survey of government auditors' self-efficacy and professional Development for improving audit quality. SpringerPlus, 5(1), 1263. https://doi.org/10.1186/s40064-016-2903-0 
Liyanarachchi, G. A., \& Namara, S. M. Mc. (2007). Time Budget Pressure in New Zealand Audit. Business Review, 9(2).

Loke, C. H., Ismail, S., \& Hamid, F. A. (2016). The perception of public sector auditors on performance audit in Malaysia: an exploratory study. Asian Review of Accounting, 24(1), 90-104. https://doi.org/10.1108/ARA-12-2013-0082

López, D. M., \& Peters, G. F. (2012). The effect of workload compression on audit quality. Auditing: A Journal of Practice \& Theory, 31(4), 139-165. https://doi.org/10.2308/ajpt-10305

Lord, A. T., \& DeZoort, F. T. (2001). The impact of commitment and moral reasoning on auditors' responses to social influence pressure. Accounting, Organizations and Society, 26(3), 215-235. https://doi.org/10.1016/S0361-3682(00)00022-2

Mahdavi, G., \& Daryaei, A. A. (2017). Factors affecting the audit process and social theories. Corporate Governance: The International Journal of Business in Society, 17(4), 770-786. https://doi.org/10.1108/CG-04-2016-0079

Malta, M. (2004). Stress at work, a concept in stress human factors limited. Business Psychology Strategy, 33(6), 125-133.

Margheim, L., Kelley, T., \& Pattison, D. (2005). An empirical analysis of the effects of auditor time budget pressure and time deadline pressure. The Journal of Applied Business Research, 21(1), 23-36. https://doi.org/10.19030/jabr.v21i1.1497

McNair, C. J. (1991). Proper compromises: The management control dilemma in public accounting and its impact on auditor behavior. Accounting, Organizations and Society, 16(7), 635-653. https://doi.org/10.1016/0361-3682(91)90017-9

McNamara, S. M., \& Liyanarachchi, G. A. (2008). Time budget pressure and auditor dysfunctional behaviour within an occupational stress model. Accountancy Business and the Public Interest, 7(1), 1-43.

Mohd Iskandar, T., Nelly Sari, R., Mohd-Sanusi, Z., \& Anugerah, R. (2012). Enhancing auditors' performance: The importance of motivational factors and the mediation effect of effort. Managerial Auditing Journal, 27(5), 462-476. https://doi.org/10.1108/02686901211227959

Mohd Nor, M. N. (2011). Auditor Stress: Antecedents and relationships to audit quality. Unpublished Doctor Thesis, Edith Cowan University, Perth, Western Australia.

Muse, L. A., Harris, S. G., \& Feild, H. S. (2003). Has the inverted-U theory of stress and job performance had a fair test?. Human Performance, 16(4), 349-364. https://doi.org/10.1207/S15327043HUP1604_2

Nakasis, K., \& Ouzouni, C. (2008). Factors influencing stress and job satisfaction of nurses working in psychiatric units: a research review. Heal Sci J., 2, 183-95.

Nasution, D., \& Ostermark, R. (2012). The impact of social pressures, locus of control, and professional commitment on auditors' judgment: Indonesian evidence. Asian Review of Accounting, 20(2), 163-178. https://doi.org/10.1108/13217341211242204

National Audit Department. (2017). Position Warrant for National Audit Department 2017.

National Audit Department. (2018). Malaysia/Mandate/Audit Acts 1975. Retrieved May 2018, fromwww.audit.gov.my

Novriansa, A., \& Riyanto, B. (2016). Role Conflict and Role Ambiguity on Local Government Internal Auditors: the Determinant and Impacts. Journal of Indonesian Economy and Business, 31(1), 63. https://doi.org/10.22146/jieb.10320

Olasanmi, O. O. (2016). Effect of ergonomic hazards on job performance of auditors in Nigeria. American Journal of Industrial and Business Management, 6(01), 33. https://doi.org/10.4236/ajibm.2016.61003

Otley, D. T., \& Pierce, B. J. (1995). The control problem in public accounting firms: An empirical study of the impact of leadership style. Accounting, Organizations and Society, 20(5), 405-420. https://doi.org/10.1016/0361-3682(95)00003-R

Paino, H., Smith, M., \& Ismail, Z. (2012). Auditor acceptance of dysfunctional behaviour: An explanatory model using individual factors. Journal of Applied Accounting Research, 13(1), 37-55. https://doi.org/10.1108/09675421211231907 
Pallant, J. (2005). SPSS survival guide. Crow's Nest, NSW: Allen \& Unwin.

Pallant, J. (2010). SPSS survival manual: a step by step guide to data analysis using SPSS. Maidenhead: Open University Press/McGraw-Hill.

Persellin, J., Schmidt, J. J., \& Wilkins, M. S. (2014). Auditor perceptions of audit workloads, audit quality, and the auditing profession. https://doi.org/10.2139/ssrn.2534492

Pietsch, C. P., \& Messier, W. F. Jr. (2017). The Effects of Time Pressure on Belief Revision in Accounting: A Review of Relevant Literature within a Pressure-Arousal-Effort-Performance Framework. Behavioral Research in Accounting, 29(2), 51-71. https://doi.org/10.2308/bria-51756

Podsakoff, N. P., LePine, J. A., \& LePine, M. A. (2007). Differential challenge stressor-hindrance stressor relationships with job attitudes, turnover intentions, turnover, and withdrawal behavior: a meta-analysis. Journal of Applied Psychology, 92(2), 438. https://doi.org/10.1037/0021-9010.92.2.438

Ponemon, L. (1992). Auditor Underreporting of Time and Moral Reasoning: An Experimental Lab Study. Contemporary Accounting Research, 9(1), 171-189. https://doi.org/10.1111/j.1911-3846.1992.tb00875.x

Qureshi, I., Jamil, R. A., Iftikhar, M., Arif, S., Lodhi, S., Naseem, I., \& Zaman, K. (2012). Job stress, workload, environment and employees turnover intentions: Destiny or choice. Archives Des Sciences, 65(8), 230-241.

Rauf, F. A., Yusoff, H., Yatim, N., Poobalan, U. R., Salleh, S. C., \& Othman, R. (2008). Public Sector Accounting Malaysian Context. Pearson Custom Publishing, Petaling Jaya

Robertson, J. C. (2007). Staff auditor reporting decisions under time deadline pressure. Managerial Auditing Journal, 22(4), 340-353. https://doi.org/10.1108/02686900710741919

Sacramento, C. A., Fay, D., \& West, M. A. (2013). Workplace duties or opportunities? Challenge stressors, regulatory focus, and creativity. Organizational Behavior and Human Decision Processes, 121(2), 141-157. https://doi.org/10.1016/j.obhdp.2013.01.008

Schultz, D., \& Schultz, S. E. (2015). Psychology and Work Today: Pearson New International Edition CourseSmart eTextbook. Routledge.

Sekaran, U. (2014). Research methods for business: A skill building approach (6th ed.). New York: John Wiley \& Sons, Inc.

Sekaran, U., \& Bougie, R. (2014). Research methods for business: a skill-building approach (6th ed.). Haddington: John Wiley \& Sons.

Shah, S. S. H., Jaffari, A. R., Aziz, J., Ejaz, W., Ul-Haq, I., \& Raza, S. N. (2011). Workload and performance of employees. Interdisciplinary Journal of Contemporary Research in Business, 3(5), 256-267.

Sincero, S. M. (2012). How does Stress Affect Performance?. Retrieved from https://explorable.com/how-does-stress-affect-performance

Smith, N. C., Simpson, S. S., \& Huang, C. (2007). Why managers fail to do the right thing: an empirical study of unethical and illegal conduct. Business Ethics Quarterly, 17(4), 633-667. https://doi.org/10.5840/beq20071743

Suhayati, E. (2012). The Influence Of Audit Fee, Audit Time Budget Pressure And Public Accountant Attitude On The Public Accountant Dysfunctional Behavior and It's Implication on Audit Quality Survey on "Small" Scale Public Accounting Firm's in Java. Journal of Global Management, 4(1), 1-24.

Sulityawati, A. I., Janie, D. N. A., \& Sulistyanti, R. (2011). The influence of Gender, Obedience Pressure, Task Complexity, Experience, and Knowledge on Audit Judgment (Empirical Study on Accounting Firms in Central Java). Paper Presented at Proceeding The Relationship between Work Stress and Auditors' Job Performance of International Accounting Conference at Accounting Department, Faculty of Economic University Negeri Surabaya, Indonesia.

Suy, R., Chhay, L., \& Choun, C. (2018). Protection and Management Policy on Angkor Wat Temple in Cambodia: An Overview. Asian Themes in Social Sciences Research, 1(1), 10-13. https://doi.org/10.33094/journal.139.2018.11.10.13

Suy, R., Choun, C., \& Chhay, L. (2018). Review of Agriculture and Rural Development to Poverty Reduction in Cambodia: SWOT Analysis. Asian Themes in Social Sciences Research, 1(1), 1-9. https://doi.org/10.33094/journal.139.2018.11.1.9 
Svanberg, J., \& Ohman, P. (2016). Does ethical culture in audit firms support auditor objectivity?. Accounting in Europe, 13(1), 65-79. https://doi.org/10.1080/17449480.2016.1164324

Svenson, O., \& Maule, A. J. (1993). Time Pressure and Stress in Human Judgment and Decision Making. Plenum Press, New York, NY and London. https://doi.org/10.1007/978-1-4757-6846-6

Sweeney, J. T., \& Summers, S. L. (2002). The effect of the busy season workload on public accountants' job burnout. Behavioral Research in Accounting, 14(1), 223-245. https://doi.org/10.2308/bria.2002.14.1.223

Syazwan Karim, M., Paino, H., Abd Jabar, F., Pauzi, M., Farahah, N., \& Abu Bakar, S. A. N. (2015). Factors Contributing to Premature Sign-Off of Audit Procedure: Evidence from Malaysia. Advanced Science Letters, 21(5), 1243-1246. https://doi.org/10.1166/asl.2015.5991

Szalma, J. L., Warm, J. S., Matthews, G., Dember, W. N., Weiler, E. M., Meier, A., \& Eggemeier, F. T. (2004). Effects of sensory modality and task duration on performance, workload, and stress in sustained attention. Human Factors, 46(2), 219-233. https://doi.org/10.1518/hfes.46.2.219.37334

Takele, A. (2018). Ethiopian Urban Land Lease Policy Analysis Implementation: Case Study on AA City Administration. International Journal of Social Sciences Perspectives, 2(2), 96-100. https://doi.org/10.33094/7.2017.2018.22.96.100

Tang, Y., \& Khan, M. B. U. (2018). Internal Law Enforcement Challenges in Bangladesh: An Analysis. Humanities and Social Sciences Letters, 6(3), 106-120. https://doi.org/10.18488/journal.73.2018.63.106.120

Utami, I., \& Nahartyo, E. (2013). The effect of Type A personality on auditor burnout: Evidence from Indonesia.

Venkatesh, V., \& Morris, M. G. (2000). Why don't men ever stop to ask for directions? Gender, social influence, and their role in technology acceptance and usage behavior. MIS Quarterly, 115-139. https://doi.org/10.2307/3250981

Viator, R. E. (2001). The association of formal and informal public accounting mentoring with role stress and related job outcomes. Accounting, Organizations and Society, 26(1), 73-93. https://doi.org/10.1016/S0361-3682(00)00002-7

Walker, R. M., Boyne, G. A., \& Brewer, G. A. (2010). Public Management and Performance: Research Directions. Cambridge, UK: Cambridge University Press. https://doi.org/10.1017/CBO9780511760587

Wang, C. M. (2006). Applying structural equation modelling to study the influence of leadership styles, job satisfaction, organization commitment and job performance: An empirical study of real estate agents in Taoyuan area. Unpublished master's thesis, National Donghwa University, Taiwan.

Werner, J. M. (2000) Implications of OCB and contextual performance for human resource management. Human Resource Management Review, 10(1), 245-261. https://doi.org/10.1016/S1053-4822(99)00036-4

Wijaya, I. A., \& Yulyona, M. T. (2017). Does Complexity Audit Task, Time Deadline Pressure, Obedience Pressure, and Information System Expertise Improve Audit Quality?. International Journal of Economics and Financial Issues, 7(3), 398-403.

Yan, H., \& Xie, S. (2016). How does auditors' work stress affect audit quality? Empirical evidence from the Chinese stock market. China Journal of Accounting Research, 9(4), 305-319. https://doi.org/10.1016/j.cjar.2016.09.001

Yang, J., Edwards, D., \& Love, P. (2014). Measuring the impact of daily workload upon plant operator production performance using artificial neural networks. Civil Engineering and Environmental Systems, 21(4), 279-293. https://doi.org/10.1080/10286608412331333220

Yap, Y. M., Chia, K. W., Tan, G. M., Ter, S. Y., \& Toh, S. Y. (2013). The relationship between work stress and auditors' job performance. Doctoral dissertation, UTAR.

Yerkes, R. M., \& Dodson, J. D. (1908). The relation of strength of stimulus to rapidity of habit formation. Journal of Comparative Neurological Psychology, 18, 459-482. https://doi.org/10.1002/cne.920180503

Zur, H. B., \& Breznitz, S. J. (1981). The effect of time pressure on risky choice behavior. Acta Psychologica, 47(2), 89-104. https://doi.org/10.1016/0001-6918(81)90001-9 